NBER WORKING PAPER SERIES

VOLUNTARY DEBT REDUCTION: INCENTIVES AND WELFARE

Elhanan Helpman

Working Paper No. 2692

NATIONAL BUREAU OF ECONOMIC RESEARCH

1050 Massachusetts Avenue

Cambridge, MA 02138

August 1988

Part of my work on this paper was done when I was a visiting scholar in the Research Department of the International Monetary Fund and part was done when I was a visiting professor at MIT. I thank Michael Dooley, Rudiger Dornbusch, Jacob Frenkel, Gene Grossman, Paul Krugman, Assaf Razin, Jeffrey Sachs and Lars Svensson for helpful comments and discussions. This research is part of NBER's research program in International Studies. Any opinions expressed are those of the author not those of the National Bureau of Economic Research. 
NBER Working Paper \#2692

August 1988

\section{VOLUNTARY DEBT REDUCTION: INCENTIVES AND WELFARE}

\section{ABSTRACT}

In an economy with a debt overhang, investment depends on expected tax rates. On the other hand, expected tax rates depend on the debt's face value. Therefore investment depends on the face value of debt. I show that this may lead to a positive or negative association between debt and investment depending on the degree of international capital mobility and attitudes toward risk. There may also exist multiple equilibria; with high and low investment levels. The paper explores the desirability of debt reduction in this environment. First, it characterizes circumstances in which debt reduction is desirable from the collective point of view of the creditors. Second, it formulates the forgiveness decision as a noncooperative game among creditors and explores the scope for debt reduction as an outcome of this game.

Elhanan Helpman Department of Economics Tel Aviv University Tel Aviv 69978 ISRAEL 


\section{Introduction}

Six years of the international debt crisis have generated many proposals for its resolution. Some proposals involve pure financial engineering while others involve real economic change. The suggestions range from market-based debt reduction schemes to unilateral moratoria on debt. Prominent among them is a call for voluntary debt forgiveness. Proponents argue that forgiveness not only serves the interest of debtor countries, but that it also would benefit the banks. High debt levels, it is claimed, bring about low incentives to adjust to the debt overhang. Low incentives to adjust lead in turn to a low capacity to service debt. If creditors were to voluntarily reduce the debt's face value they would promote adjustment. The resulting greater capacity to service debt would more than compensate them for any initial losses (see Sachs (1988) for the original argument).

Two types of adjustment bear on the issue of debt relief:

macroeconomic policies in general and the debtor country's investment level in particular. Better policies and more investment raise future income, thereby increasing the capacity to service debt. In order to rigorously deal with policy responses it is necessary to employ an explicit model of government behavior. But no accepted model is available for this purpose. For this reason I focus instead on market outcomes and investment-driven adjustments. My study is designed to explore in a systematic way the scope for voluntary debt reduction. 
Among the many dimensions of the problem at hand I concentrate on three: the degree of international capital mobility, attitudes toward risk, and the degree of cooperation among creditors. These features prove to be important. I show, for example, that in the absence of international capital mobility and in the presence of high risk aversion in the debtor country the banks cannot gain from a voluntary write-down of debt. This result is independent of the degree of cooperation among them. In other cases forgiveness may or may not serve the interest of creditors. When it is in the collective interest of creditors to provide debt reduction, however, the prospects for forgiveness may hinge on the degree of cooperation among them.

The paper is structured as follows. In the next section I describe the debtor's repayment behavior as a function of its economic performance. Full repayment takes place as long as revenue raised by a tax on random output suffices to cover debt service without the tax rate exceeding a feasible maximal level. In other cases the tax rate ceiling determines repayment, which equals tax revenue. In Section III I derive a formula for the valuation of these repayments on international financial markets, and use it to determine the value of debt on secondary markets as well as the secondary market price and discount. This information is used in Section IV to evaluate the effect on prices of a facility that purchases cebt on secondary markets in order to forgive it. It is shown that the resulting price increases can be substantial even when investment does not change. 
I explore the relationship between debt and investment in Section $V$. This relationship is shown to depend on the degree of capital mobility and attitudes toward risk. In the absence of international capital flows and high risk aversion in the debtor country a larger debt is associated with more investment. In all other cases larger debts imply lower investment, and there may exist multiple equilibria that differ in investment levels. With multiple equilibria small changes in debt may bring about sharp investment responses, because the economy may jump from one equilibrium to another.

Section VI deals with welfare implications of debt reduction. I show that debtors gain from debt reduction. Creditors lose whenever debt reduction depresses investment. But creditors may lose or gain when relief stimulates investment. Gains by creditors are particularly likely if multiple equilibria exist and the debtor country is trapped in a low investment equilibrium. In this case debt reduction may force a switch to a Pareto-superior high investment equilibrium. This analysis identifies circumstances in which cooperating creditors would provide voluntary debt relief.

In Section VII I consider the scope for debt reduction in the absence of cooperation. For this purpose I formulate a non-cooperative game in voluntary debt reductions. In the presence of a single investment equilibrium and where scope exists for collective debt relief, non-cooperative actions yield voluntary debt reductions if the inital debt 
is sufficiently large. In the presence of multiple investment equilibria the solution set of the non-cooperative game may contain an equilibrium with debt reduction together with an equilibrium without debt reduction. Some policy implications of these results are discussed in the closing section.

\section{Repayment Structure}

For the purpose of this study I employ a variant of the model developed in Helpman (1988). The entire future is collapsed into a single period. The Debtor country's output in that period is a random variable given by $\tilde{\theta} E(I)$, where $\tilde{\theta}$ denotes a random productivity shock, $I$ is the current period's investment level, and $E(\cdot)$ is an increasing concave function representing the country's activity level in production. In this section the investment level is predetermined. States of nature are identified with productivity shock levels; i.e., $\bar{\theta}$ obtains the value $\theta$ in state $\theta$.

The government has an external debt $D$ and its debt service payments are $R D$, where $R$ is one plus the interest rate. All these variables are predetermined from the point of view of the current discussion. The government services debt from tax revenue. It can tax output at any desirable rate up to a ceiling $t \leq l$. A debt problem prevails in the sense that there exist states in which the highest possible tax revenue is insufficient to cover debt service payments. Namely, $\operatorname{Prob}[t \bar{\theta} E(I)<R D]>0$. Therefore there exists a critical state, defined by 


$$
\theta_{c}(D, I)=R D / t E(I)
$$

such that debt is fully repaid in states $\theta \geq \theta_{c}$ (D,I) but cannot be fully repaid in states $\theta<\theta_{c}(D, I)$.

The government uses an income tax at the state-contingent rate $\tau(\theta ; D, I)$ in order to raise revenue for debt service payments. It defaults on its payments only when they exceed its taxing capacity, but it pays in such states its maximum tax revenue. In other states it raises the precise revenue needed for debt service payments. This specification is the same as in Helpman (1988, Section IX). Therefore,

$$
r(\theta ; \mathrm{D}, \mathrm{I})=\left[\begin{array}{lll}
\tau & \text { for } & \theta \leq \theta_{\mathrm{c}}(\mathrm{D}, \mathrm{I}), \\
\mathrm{RD} / \theta \mathrm{E}(\mathrm{I}) & \text { for } & \theta \geq \theta_{\mathrm{c}}(\mathrm{D}, \mathrm{I}) .
\end{array}\right.
$$

Creditors receive state-contingent payments $r(\theta ; D, I) \theta E(I)$, which are given by

$$
T(\theta ; D, I)=\left[\begin{array}{lll}
\tau \theta E(I) & \text { for } & \theta \leq \theta_{c}(D, I), \\
R D & \text { for } \theta \geq \theta_{c}(D, I) .
\end{array}\right.
$$

This completes the description of payments in the single future period. The resulting repayment profile is depicted in Figure 1. As long as investment is constant the same repayment profile arises when the 
government applies a state independent tax rate $t$ and redistributes revenue in excess of debt service payments to the public in a lump-sum fashion. The tax system, however, affects investment incentives; a given debt level brings about different investment levels under different tax structures (see Helpman (1988, Section IX)). This point is further discussed in Section VIII.

\section{Debt Valuation ${ }^{1}$}

In this section I discuss the valuation of debt on secondary markets. I assume that these markets are part of the international financial system and that debt repayments (3) are too small to affect state-contingent marginal valuations in this system. For simpliciy let the marginal valuations be the same in all states, and let $\mathrm{R}-1$ be the real interest on safe loans. Then every uncertain future stream of payments is valued at its discounted expected value. In particular, the stream of payments by the debtor to its creditors has a market value of

$$
\mathrm{V}(\mathrm{D}, \mathrm{I})=\mathrm{R}^{-1} \int_{0}^{\infty} \mathrm{T}(\theta ; \mathrm{D}, \mathrm{I}) \mathrm{dG}(\theta)
$$

where $G(\theta)$ is the probability distribution function over states. Using (3) this can be expressed as

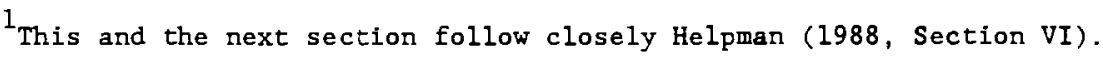




$$
V(D, I)=D-D G\left[\theta_{c}(D, I)\right]+\int_{0}^{\theta_{c}(D, I)} \theta[t E(I) / R] d G(\theta) .
$$

This function is increasing in both arguments, concave in debt, concave in investment, $V(0, I)-0$, and $V_{D}(0, I)=1$, as depicted in Figure 2.

The price of a unit of debt in the secondary market is

$$
P(D, I)-V(D, I) / D
$$

Using (5) it can also be expressed as

$$
\mathrm{P}(\mathrm{D}, \mathrm{I})-\Pi(\mathrm{D}, \mathrm{I})+[\mathrm{I}-\Pi(\mathrm{D}, \mathrm{I})] \mathrm{E}\left[\mathrm{t} \bar{\theta} \mathrm{E} / \mathrm{RD} \mid \bar{\theta}<\theta_{\mathrm{c}}(\mathrm{D}, \mathrm{I})\right],
$$

where $\Pi(D, I)=1-G\left[\theta_{c}(D, I)\right]$ is the probability that $\bar{\theta} \geq \theta_{c}(D, I)$ and $E[\cdot]$ is the expected value of the repayment share $t \bar{\theta} \mathrm{E} / \mathrm{RD}$ conditional on the productivity shock being smaller than $\theta_{c}(D, I)$. Hence, the equilibrium price--equal to the mean repayment share--is a weighted average of one (full repayment) and the mean repayment share in the low productivity states in which debt is only partially repaid.

The price of a unit of debt on the secondary market is represented in Figure 2 by the slope of a ray through the origin (see (6)). Thus, for example, the slope of ray $\mathrm{OA}_{1}$ represents the price when debt is $D_{1}$. The smaller the debt the higher its price and the smaller its discount (the discount equals one minus the price). The price approaches one and 
the discount approaches zero as debt approaches zero. Higher debt levels lead to lower prices on the secondary market because the larger the debt the smaller the set of states in which debt is fully repaid and the lower repayment per-unit debt in states with partial repayment (the latter results from the fact that total payments in these states do not change with the level of debt; see Figure 1). In terms of (7) higher debt levels reduce the probability of full repayment as well as the conditional expected repayment share in states of partial repayment.

\section{Price Effects of Debt Reduction}

There exist several programs of debt forgiveness (see, for example, Cline (1987)). Some of them, such as Kenen's (1983), propose to establish an international facility that will buy debt on secondary markets and forgive it (see Corden (1988a) for a review). As pointed out by Dooley (1988), existing market discounts cannot be used to assess the cost of debt forgiveness, because the anticipation of forgiveness raises market prices. My model suggests that indeed the lower the outstanding debt the higher its price on the secondary market. Rational expectaions imply that in equilibrium the purchase price equals the post-purchase price on the secondary market. For suppose it is higher. Then every remaining holder of debt wants to sell for a somewhat lower price. And if it is lower, an owner of a unit of debt prefers to sell it after the reduction of debt. For these reasons (6) or (7) can be used to calculate the purchase price for an international facility that intends to forgive debt. In this 
calculation $D$ denotes the remaining debt.

Suppose, for example, that an international facility buys and forgives $\Delta$ of debt (it may buy more, but the following analysis depends only on the amount forgiven). Then our analysis suggests that $P(D-\Delta, I)$ describes the unit value of remaining debt. When the productivity shock is uniformly distributed on the interval $[0,1]$ (7) yields (assuming that the critical values $\theta_{c}(\cdot)$ before and after the purchase are strictly between zero and one)

$$
P(D-\Delta, I)=1-\frac{1}{2} \theta_{c}(D-\Delta, I)=1-\frac{1}{2} \theta_{c}(D, I)\left(1-\frac{\Delta}{D}\right) .
$$

Hence, if $\theta_{c}(D, I)-.8$ (the probability of full repayment is initially 20 percent), debt is valued at 60 cents to the dollar. And if the facility wants to buy 20 percent of the debt with an intention to forgive it (i.e., $\Delta / D-.2$ ), the price of debt goes up to 68 cents to the dollar. Thus, 20 percent forgiveness increases prices by close to 14 percent.

This calculation suggests that a great deal of the corporation's resources will go to the creditors, despite the facility's intention to help the debtor. This is in line with Dooley's argument. If, for example, debt is $\$ 100$ billion and the facility buys back 20 percent, it spends $\$ 13.6$ billion. The remaining claims of the creditors are worth $\$ 54.4$ billion. Therefore, in order to reduce the value of claims by $\$ 5.6$ billion the facility has to spend $\$ 13.6$ billion. More generally, since 
$p(O, I)=1$ (i.e., total debt forgiveness raises the price to its face value), the price goes up to as close as desired to 1 for sufficiently large debt forgiveness levels. Hence, if initially debt is traded at a high discount, say at 20 cents to the dollar (as some of Peru's debt was traded), a sufficiently high degree of debt forgiveness by an international facility that buys debt on the secondary market will bring about huge capital gains to the creditors with relatively little debt relief to the debtor. All this assumes constant investment. As I show below, however, the response of investment to debt reduction has important effects on secondary market values.

\section{Investment}

I deal in this section with the effects of debt on investment. This analysis is of interest in its own right, but it also provides an essential ingredient in the following evaluation of the case for voluntary debt reduction. At this stage it is sufficient to observe that (5) implies that debt reduction does not help the creditors if it depresses investment or raises it only slightly (because the value of debt increases in both debt and investment). For this reason voluntary debt reduction requires a sufficiently strong investment stimulus. Naturally, in a broader contex of adjustment there exist additional channels of influence. In this study; however, I deal only with investment. 
In order to deal with these concernes we need to fill in additional details of the model. Assume that the debtor country's firms trade shares in a competitive stock market in the manner suggested by Diamond (1967). Using the terminology of Helpman and Razin (1978), E(I) denotes the number of real equities. Given a real equity price $q$ the net value of firms is $\mathrm{qE}(\mathrm{I})-\mathrm{I}$. Firms choose investment to maximize their net value, which implies the first order condition $\mathrm{qE}^{\prime}(\mathrm{I})=1$. Hence, the supply price of real equities is

$$
q_{s}(I)=I / E^{\prime}(I) \text {. }
$$

Higher investment levels lead to higher supply prices of real equities, as depicted in Figure 3. If we were to draw the supply price as a function of the stock of real equities rather than the investment level, it would represent a regular supply curve. However, since the stock of real equities increases with investment I refer to the plott of $q_{s}(I)$ in the firgure as a supply curve.

In order to determine the level of investment we also need a demand curve. The nature of this curve depends on institutions, the distribution of the productivity shock, preferences, as well as additional features. In particular, it depends on the degree of international capital mobility allowed by the debtor country. I will deal with two extreme cases; free capital mobility and a binding quantative restriction on capital flows. 


\section{Free capital mobility}

In the presence of free capital mobility the price of every asset is determined by its value on the international capital markets as the discounted expected present value of its future return. Thus, if $\eta(\theta ; \mathrm{D}, \mathrm{I})$ represents an asset's state contingent return, the market prices the asset according to

$$
\mathrm{q}_{\mathrm{d}}(\mathrm{D}, \mathrm{I})=\mathrm{R}^{-1} \int_{0}^{\infty} \eta(\theta ; \mathrm{D}, \mathrm{I}) \mathrm{dG}(\theta)
$$

This representation underlines the dependence of the asset price on debt and investment, which are the subject of this study. Naturally, there exist many assets whose return structure does not depend on debt or investment; their price does not dependend on these variables either. The return on a unit of real equity equals the after tax value of $\theta$. Therefore for real equities

$$
\eta(\theta ; D, I)=[1-\tau(\theta ; D, I)] \theta
$$

Formula (11) applies to every state contingent tax structure. For the particular structure given in (2) we can combine (2), (10), and (11) to obtain

$$
\mathrm{q}_{\mathrm{d}}(\mathrm{D}, \mathrm{I})-\mathrm{R}^{-1} \dot{\theta}-\mathrm{R}^{-1} \mathrm{t} \int_{0}^{\theta_{c}(D, I)} \theta \mathrm{dG}(\theta)-\left[1-\mathrm{G}\left[\theta_{\mathrm{c}}(\mathrm{D}, \mathrm{I})\right]\right] \mathrm{D} / \mathrm{E}(\mathrm{I}),
$$


where $\bar{\theta}$ denotes the mean of $\vec{\theta}$. This price declines in debt and increases in investment. It declines in debt because the larger the debt level the higher the tax rates in states with full repayment and the lower the after tax return on equity. Higher debt also reduces the set of states in which there is full repayment, but this has a second order effect. The demand price increases in investment because the larger the investment level the larger the tax base and the lower the tax rates in states of full repayment. Hence, for positive debt levels the demand price rises with investment, as depicted in Figure 3 (changes in the set of states with full repayment have again second order effects). The demand price function also satisfies

$$
\mathrm{q}_{\mathrm{d}}(0, \mathrm{I})=\mathrm{R}^{-1} \bar{\theta}
$$

and

$$
\lim _{\mathrm{I} \rightarrow+\infty} q_{d}(D, I)-R^{-1} \bar{\theta} \quad \text { whenever } \quad \lim _{I \rightarrow+\infty} G\left[\theta_{c}(D, I)\right]=0 .
$$

Therefore, in the absence of debt the demand curve is horizontal at a level that equals the discounted mean of the productivity shock, and whenever the condition on $\theta_{c}(\cdot)$ is satisfied the demand price approaches this value asymptotically as the investment level goes to infinity.

Figure 3 describes a situation with a unique equilibrium, determined by the intersection of the demand and supply curves at point 1 . These 
curves were generated from explicit functions and a debt level $D=0.25 .^{2}$ Figure 4 describes curves that were generated from the same functions with a debt level $\mathrm{D}=0.50$. They intersect twice and the demand curve is below the supply curve at low investment levels. Consequently, there are three equilibria; at points 1,2 , and a third one with zero investment. The third equilibrium is supported by every equity price in the range $[\bar{q}, q]$. The first and third equilibrium are stable under the usual adjustment process while the second is not. Inspection of Figures 3 and 4 and the fact that the demand curve shifts up when debt declines imply:

Proposition 1: In the presence of free capital mobility debt reduction stimulates investment at stable equilibria with positive investment.

First, observe that there exists a unique equilibrium for sufficiently low debt levels as long as the supply price at zero investment is below the expected present value of $\tilde{\theta}$, and that positive investment prevails in this equilibrium. Therefore, whenever there exists an equilibrium with zero investment sma11 debt reductions may not eliminate it but sufficiently large debt reductions will. Second, in the presence of multiple equilibria the economy can be trapped in a low investment equilibrium, which hurts the creditors and the debtor (see the following section). Nevertheless, no competitive forces ensure a switch to a better equilibrium. When a single financial investor calculates the benefits of

\footnotetext{
${ }^{2}$ In this example the following parameters and functions are used: $\mathrm{R}-1$, $t=0.5, \quad \vec{\theta}$ is uniformly distributed on $[0,1]$, and $E(I)=1-10 \log 0.27+\operatorname{lol} 0 \mathrm{~g}(0.27+0.1 I)$.
} 
an additional unit of equity holding he takes as given the tax structure and therefore the expected net return on equity. If he expects lower tax rates he is willing to pay a higher price for equity. Higher equity prices lead to higher investment. Higher investment, in turn, reduces tax rates in states of full repayment, thereby justifying the expected high return on equity. This mechanism is responsible for the multiplicity of equilibria. ${ }^{3}$

Figure 5 describes the relationship between debt and equilibrium investment in the example given in footnote 2 (it is also easy to see the following results by direct inspection of Figures 3 and 4 ). For debt levels below $D_{L}$ or above $D_{U}$ there exists a unique quilibrium, which features positive investment in the former interval and zero investment in the latter. For debt levels in the interval $\left[D_{L}, D_{U}\right]$, however, there exist two equilibria; one with positive investment and one with none. This feature can bring about sharp investment responses to small changes in debt. In order to appreciate the importance of this point consider the following experiments. First, suppose debt is close to $D_{U}$ but below it and the economy is at the positive investment equilibrium. A small increase in debt that brings the debt level above $D_{L}$ shifts the economy to the single no investment equilibrium. Hence, a small debt increase brings abount a decline of investment from above $I_{U}$ to zero. Next, suppose debt is close to $D_{L}$ but above it and the economy is trapped at

\footnotetext{
${ }^{3}$ Multiple equilibria appear also in other models of debt; see, for example, Eaton (1987) and Calvo (1988).
} 
the no investment equilibrium. Now a small debt reduction that brings the debt level below $D_{L}$ shifts the economy to the single positive investment equilibrium. Hence, a small debt reduction raises investment from zero to a level that exceeds $I_{L}$.

Proposition 2: In the presence of free capital mobility a debt increase may bring about a discontinuous drop in investment and a debt reduction may bring about a discontinuous rise in investment.

As in many other models with multiple equilibria it is hard to predict which equilibrium the economy will choose. It is, however, clear that for debt levels in the interval $\left[D_{L}, D_{U}\right]$ the economy settles on the positive investment equilibrium when portfolio holders expect low future tax rates and on the no investment equilibrium when portfolio holders expect high future tax rates. Hence, expectations of future tax rates determine the quilibrium outcome, and both low and high tax rate expectation are self fulfilling.

\section{No capital mobility}

Next consider the case with no international capital mobility in the debtor country (the following results apply also to cases of binding quantative restrictions on capital movements). In this case investment equals saving and we need to specify saving behavior in order to analize 
investment levels. I employ a simple two period model. ${ }^{4}$ The second period was described in the previous sections. In the first period residents of the debtor country consume $c_{0}$ and aquire $e$ real equities. Firms invest I. Let $y$ be output in this period. Then the representative resident faces the budget constraint

$$
c_{0}+q e \leq y+q E(I)-I \text {, }
$$

where the last two terms on the right hand side represent the net value of initial share holdings. ${ }^{5}$ Individuals evaluate first period consumption and portfolio holding by means of their discounted expected utility

$$
U\left(c_{0}, e ; D, I\right)-v\left(c_{0}\right)+\delta \int_{0}^{\infty} u[\eta(\theta ; D, I) e] d G(\theta)
$$

where $v(\cdot)$ and $u(\cdot)$ are concave functions, $\delta$ denotes the subjective discount factor, and $\eta(\theta ; D, I)$--which represents the return on portfolio holding--represents second period consumption. Maximization of $U(\cdot)$ subject to (13) yields the first order condition

$$
q-s\left(c_{0}, e ; D, I\right)
$$

\footnotetext{
${ }^{4}$ This subsection follows closely Helpman (1988, Section IX).

${ }^{5}$ It is easy to add a domestic bond market to the model. However, in the absence of capital movements this market has to clear at zero indebtness. Consequently, the following analysis would not be affected by this modification. In fact, one can calculate from what follows the equilibrium interest rate on this bond market.
} 
where $s(\cdot)=U_{\mathrm{e}}(\cdot) / \mathrm{U}_{\mathrm{c}_{0}}(\cdot)$ denotes the marginal rate of substitution between real equity and first period consumption, defined by

$$
\mathbf{s}\left(c_{0}, e ; D, I\right) \equiv \delta \int_{0}^{\infty} u^{\prime}[\eta(\theta ; D, I) e] \eta(\theta ; D, I) d G(\theta) / v^{\prime}\left(c_{0}\right)
$$

This function is increasing in $c_{0}$ as long as $v(\cdot)$ is strictly concave and declining in $e$ as long as $u(\cdot)$ is strictly concave. The latter applies whenever residents of the debtor country are risk averse. The separate functional forms for first and second period utility are designed to separate considerations of second period risk aversion from intertemporal substitution.

Equations (15) and (16) apply to every distribution of returns on real equity and can be combined to yield a demand price for equities. In our case (2) and (11) can be used to derive the rate of return function. They imply that in states of full repayment the rate of return is declining in debt and increasing in investment, and the rate of return is constant in states of partial repayment. Hence, if the Arrow-Pratt measure of relative risk aversion $\rho(c)=-u^{\prime \prime}(c) c / u^{\prime}(c)$ is larger than one the product $u^{\prime}[\eta(\theta ; D, I)] \eta(\theta ; D, I)$ increases in debt and declines in investment. If the measure of relative risk aversion is smaller than one this product declines in debt and increases in investment. Therefore we have 
Lemma: If the relative degree of risk aversion is larger than one $s\left(c_{0}, e ; D, I\right)$ increases in debt and declines in investment, and if the relative degree of risk aversion is smaller than one $s\left(c_{0}, e ; D, I\right)$ declines in debt and increases in investment.

The intiution behind this result can be explains as follows. An increase in debt reduces the return to equity in every state with full repayment. This generates two effects; an income and a rate of return effect. The income effect stems from the fact that given equity holdings future income falls in some states but does not rise in others. Consequently, the value of assets that transfer income from the present to the future increases, including the value of equity. On the other hand, a decline in the rate of return on equity reduces its value as an asset. Therefore the net effect on $s(\cdot)$ depends on whether the income effect dominates the rate of return effect or vise versa. The income effect dominates under high risk aversion (i.e., $\rho(c)>1$ ) while the rate of return effect dominates under low risk aversion. 6

Next observe that in the absence of capital mobolity debtor country residents hold all domestic equity; i.e., e-E(I). Together with (13) this condition implies $c_{0}=y-I$. Namely, first period consumption equals output minus investment. Subsituting these results into (15) yields the derived demand price function

6 A diagramatic exposition of the income effect is available in Helpman (1988). See also Corden (1988b). 


$$
q_{d}(D, I)=s[y-I, E(I) ; D, I]
$$

Investment affects the demand price through three channels: first period consumption, the stock of real equities, and the rate of return on equity. Higher investment reduces the demand price via the first two channels and reduces it via the third channel if and only if the degree of relative risk aversion is larger than one (see Lemma). The last condition also ensures that the demand price increases in debt. Hence, the demand curve slopes downward when risk aversion is high, as in Figure 6, and debt reduction shifts the demand curve downwards, thereby depressing investment.

Proposition 3: If there is no international capital mobility and the degree of relative risk aversion is larger than one, then :

(a) A unique level of investment is associated with every debt level;

(b) Debt reduction depresses investment.

When the degree of relative risk aversion is smaller than one the affect of investment on first period consumption and the stock of real equities may cause the demand curve to slope downward. In this case, however, debt reduction shifts it upwards (see the Lemma), thereby stimulating investment. It is also clear that even if--as a consequence of low risk aversion--the demand curve slopes upwards, debt reduction stimulates investment at every stable equilibrium point (i.e., points at 
which the demand curve is flatter than the supply curve), because it brings about an upward shift of the demand curve.

Proposition 4: If there is no international capital mobility and the degree of relative risk aversion is smaller than one debt reduction increases investment at every stable equilibrium with positive investment.

Propositions $1-4$ summerize the effect of debt reduction on investment; it can be positive or negative, depending on the degree of capital mobility and attitudes toward risk. 7

More insight can be gained by identifying links among these results. Free capital mobility leads to a linear evaluation of equities.

Therefore, in the presence of restrictions on capital mobility one expects low risk aversion to generate results that are closer to the case of perfect capital mobility than high risk aversion, which indeed happens. In particular, risk neutrality implies (see (16) and (17))

$$
\mathrm{q}_{\mathrm{d}}(\mathrm{D}, \mathrm{I})=\delta \mathrm{u}^{\prime}(0) \int_{0}^{\infty} \eta(\theta ; \mathrm{D}, \mathrm{I}) \mathrm{dG}(\theta) / \mathrm{v}^{\prime}(\mathrm{y}-\mathrm{I}) .
$$

In this case the income effect vanishes and debt reduction increases the

${ }^{7}$ Estimates of relative risk aversion are typically larger than one. In linear regressions of the investment/GDP ratio on the debt/GDP ratio for the 15 most heavily indebted countries I found only in 8 of them a negative coefficient that is significantly different from zero (the sample period is 1973 to 1986 or 1987). 
demand price via the rate of return effect, just as in the case of free capital mobility. The price is also proportional to the mean return, except that the factor of proportionality depends on investment. The latter dependence disappears altogether when the elasticity of substitution between present and future consumption goes to infinity. Under these circumstances the effects of debt forgiveness on investment are the same as under free capital mobility. For this reason we have:

Proposition 5: If there is no international capital mobility, the degree of relative risk aversion is smaller than one, and the elasticity of intertemporal substitution is sufficiently high, the relationship between debt and investment is the same as in the case of free capital mobility.

I should like to emphasized that the similarity in results that is pointed out in this proposition applies not only to the response of investment to debt but also to the possibility of multiple equilibria.

\section{Welfare}

The typical analysis of the affect of debt on investment does not draw a clear distinction between equilibrium and welfare maximizing investment levels (see, for example, Sachs (1988)). ${ }^{8}$ This difference is, however, important. For example, models with optimal investment preclude the possibility of multiple equilibria of the type described in the

${ }^{8}$ See also Krugman (1988) and Corden (1988c) for reviews. 
previous section. I assume that investment is governed by market forces. The following analysis is concerned with the welfare implications of debt reduction for the debtor and the creditors, taking into account investment responses. I emphasize the role of the degree of capital mobility and attitudes toward risk.

As far as the debtor is concerned, its welfare is measured by the utility level that is attained when (14) is maximized subject to (13). Let the implied indirect utility function be $U^{\mathrm{IN}}[q, y+q E(I)-I ; D, I]$; it depends on the price of equity, net wealth, and directly on debt and investment which determine the rate of return on equity via the tax rates. It has the usual properties of indirect utility functions. Hence, 9

$$
\begin{aligned}
& d U^{I N} / v^{\prime}\left(c_{0}\right)-[E(I)-e] d q+\left[q^{\prime}(I)-1\right] d I \\
& +\delta e \int_{\theta_{c}(D, I)}^{\infty} u^{\prime}[\eta(\theta ; D, I) e]\left[\eta_{D}(\theta ; D, I) d D\right. \\
& \left.+\eta_{I}(\theta ; D, I) d I\right] \operatorname{edG}(\theta) / v^{\prime}\left(c_{0}\right) .
\end{aligned}
$$

The first term on the right hand side represents the assets terms of trade effect. If there are restrictions on capital mobility and $e-E$ (I) it is zero. In the presence of free capital mobility I make the reasonable assumption that domestic residents hold only part of their equity; i.e.,

${ }^{9}$ Changes in debt and investment change the critical state $\theta_{c}$. Changes in the critical state, however, have second order effects (because the rate of return function is continuous despite the fact that its derivatives are not) and are therefore disregarded in this formula. 
$E(I)>e$. In this case debt reduction raises investment and the price of equity at stable equilibria (unless the economy jumps to a different equilibrium) and the debtor gains on account of better asset terms of trade (see Proposition 1). ${ }^{10}$ The second term is always zero, because firms maximize net value (see (9)). The third term describes the direct effect of debt and investment on welfare through the rate of return, or equivalently, through the tax rates. Debt reduction raises investment at a stable equilibrium when capital moves freely. In this case tax rates decline in states of full repayment both as a result of lower debt service payments and higher investment. Consequently, the rate of return rises in these state and the debtor gains.

In the absence of capital mobility only changes in the rate of return affect the debtor's welfare, and I have shown in the previous section that under these circumstances debt reduction increases investment at stable equilibria if and only if the degree of relative risk aversion is smaller than one (see Propositions 3 and 4). Hence, when the degree of relative risk aversion falls short of one debt reduction increases the rate of return on equity in states of full repayment, both through the direct effect of lower debt and the indirect investment effect on tax rates. Consequently, the country gains. In the absence of capital mobility and a larger than one degree of relative risk aversion debt forgiveness reduces investment. In this case the rate of return rises as a result of the

${ }^{10}$ In the presence of free capital mobility the country may be trading additional assets. My results do not change as long as the price of these assets is not influenced by either debt or investment. 
direct effect of lower debt and falls as a result of the indirect investment effect on tax rates. The former effect dominates, however, and rates of return increase in states of full repayment. ${ }^{11}$ This establishes

Proposition 6: The debtor gains from debt reduction when the economy is at a stable equilibium and does not jump to another equilibrium.

Note that in the absence of capital mobility the response of investment to debt reduction hurts the debtor whenever the degree of relative risk aversion exceeds one (it is welfare increasing in the other case). We have established, however, that this negative feedback does not suffice to make the debtor worse off.

Next I considered the welfare ranking of multiple equilibia. As before, in the absence of capital mobility e-E(I) and in the presence of capital mobility $e \leq E(I)$. Under these conditions we have the following result:

11 Proof: From Proposition 3 we know that under these circumstances debt forgiveness depresses investment. On the other hand,

$$
q_{d}(D, I) \equiv s[y-I, E(I) ; D, I]-q_{s}(I) \text {. }
$$

Lower investment implies a lower value of $q_{s}(\cdot)$ and a higher value of $s(\cdot)$ for constant rates of return. Therefore, given that the relative degree of risk aversion is larger than one, rates of return in states of full repayment have to be higher for the demand price for equity to equal the supply price (see Lemma); namely,

$$
\eta_{D}(\theta ; D, I)+\eta_{I}(\theta ; D, I) d I / d D>0 \text { for } \theta>\theta_{c}(D, I)
$$


Proposition 7: Given the degree of capital mobility and the level of debt the debtor prefers an equilibrium with higher investment.

Proof: First consider the case of no capital mobility. (Naturally, in this case multiplicity of equilibria can arise only when the degree of relative risk aversion is smaller than one and there is sufficient intertermporal substitution in consumption (see Proposition 5).) Figure 7 presents two equilibrium points, 1 and 2 . The curve TT describes the tradoff between first period net resources $y-I$ and real equity $E(I)$. In the absence of capital mobility first period consumption and equity holdings have to be on this curve. An equilibrium is characterized by the tangency of an indifference curve to TT, where the indifference curve is defined by combinations of $\left(c_{0}, e\right)$ that maintain a constant level of $U\left(c_{0}, e ; D, I\right)$ (defined in (14)) and $I$ is the investment level at the tangency point. Points 1 and 2 satisfy this requirement. Since these indifference curves have the usual shape, they have to intersect. In the figure they intersect at point 3 . Now, since higher investment implies lower tax rates, $U\left(c_{0}, e ; D, I_{2}\right)>U\left(c_{0}, e ; D, I_{1}\right)$ for all $\left(c_{0}, e\right)$, and in particular for the pair at point 3 . This establishes $\mathrm{U}_{2}>\mathrm{U}_{1}$.

In the presence of capital mobility the production point is on TT but the consumption point can be anywhere on the implied budget line. The production point is determined by the tangency of a line with slope $\mathrm{q}_{\mathrm{d}}(\mathrm{D}, \mathrm{I})$ (defined in $(12)$ ) to $T T$, where $\mathrm{I}$ is the investment level at this point. The resulting line is the budget line on which consumption is 
chosen. Point 1 in Figure 8 describes a production equilibrium. The corresponding consumption point is $1^{\prime}$, at which an indifference curve for the investment level $I_{1}$ is tangent to the budget line. Since $l^{\prime}$ is to the left of $1, e<E\left(I_{1}\right)$. Now suppose that 2 is also a production equilibrium with higher investment. Then the budget line that is tangent to TT at 2 (not drawn) intersects the indifference curve. It implies that with preferences $U\left(c_{0}, e ; D, I_{1}\right)$ it is now possible to reach a higher welfare level. Since $U\left(c_{0}, e ; D, I_{2}\right)>U\left(c_{0}, e ; D, I_{1}\right)$, it is certainly possible to reach a higher welfare level with $U\left(c_{0}, e ; D, I_{2}\right)$. Hence, the equilibrium with higher investment is preferable.

I have shown that the debtor prefers equilibria with higher investment. But so do the creditors. Their welfare is measured by the market value of debt $V(D, I)$ (see (5)). Since this function increases in investment,

Proposition 8: Given the level of debt creditors prefer an equilibrium with higher investment.

Creditors prefer equilibria with higher investment, because the higher the investment level the larger the set of states with full repayment and the larger repayment per unit debt in states of partial repayment. Since the debtor also prefers equilibria with higher investment, no conflict arises between the debtor and the creditors in the ordering of these equilibria. Nevertheless, when the economy settles on a low investment equilibrium 
they cannot switch to a better one without explicit coordination.

Now consider the incentive of creditors to write down debt. In this section they are treated as a single entity; the incentives of individual creditors are discussed in the following section. First, observe that a debt write-down has a direct adverse effect on the creditors' welfare, because $V(D, I)$ increases in $D$. Therefore creditors benefit from debt relief only when it stimulates investment to a sufficiently large degree so as to outweight the negative direct effect. Consequently, voluntary debt reduction will not be observed when it depresses investment. In view of Proposition 3 this implies

Proposition 9: If there is no international capital mobility and the degree of relative risk aversion is larger than one, creditors do not benefit from debt reduction.

In other cases creditors may or may not benefit from debt reduction. Take, for example, the case in which a unique equilibrium exists for every debt level. Let $I(D)$ be investment as a function of debt, assumed to be differentiable. Then from (5) we obtain

$$
\frac{d}{d D} V[D, I(D)]-1-G\left(\theta_{c}[D, I(D)]\right)+\int_{0}^{\theta} c^{(D, I)} \theta\left(t E^{\prime}[I(D)] / R\right) d G(\theta) I^{\prime}(D)
$$

For $D=0$. this expression is equal to one, implying that the market value of debt rises with its face value for small debt levels even when one 
takes account of changes in investment. It is also clear that for sufficiently large values of debt $1-G(\cdot)$ is close to zero. Therefore, if $I^{\prime}(I)<0$ the right hand side may be negative for large debt levels, which would imply a market value that declines with debt. Figure 9 depicts two simulated market value curves from the same functional forms, each panel representing a different value of a parameter a in the function $E(I) .^{12}$ In the upper panel market value rises with debt for all debt lelels. In the lower panel market value rises for low debt levels and declines thereafter. In the first case creditors have no incentive to reduce debt. In the second case creditors benefit from debt reduction when $D>D_{0}$ (see also Sachs (1988), Krugman (1988), and Froot (1988)). Whenever debt exceeds $D_{0}$ creditors jointly benefit from its reduction to $\mathrm{D}_{0}$. In addition, the debt's market value may drop discontinuousely in response to an increase in its face value when there exist multiple equilibria, as I explained in what follows. Therefore,

Proposition 10: If there is free capital mobility or there is no capital mobility but the relative degree of risk aversion is smaller than one, there may exist sufficiently large debt levels at which the creditors benefit from debt reduction.

Observe that a negative effect of higher debt on Investment does not guarantee voluntary debt reduction. The point is that even under these

${ }^{12}$ The curves in Figure 9 were simulated from the following data: $R=1$, $t=1 / 2, \quad G(\theta)=1-\exp (-\theta)$, and $E(I)=a+\log 2+\log (0.5+I)$. In the upper panel $\mathrm{a}=1$; in the lower panel $\mathrm{a}=0.4$. 
circumstances the market value of debt may be rising with its face value, and even when it does not always rise with the debt's face value voluntary debt reduction requires the inital debt to be sufficiently large.

Farticularly interesting features of the debt relief problem arise when there are multiple equilibria. Consider the situation described in Figure 5, where two equilibria exist for every debt level in the range $\left[D_{\mathrm{L}}, \mathrm{D}_{\mathrm{U}}\right]$. This may arise in the presence of unrestricted capital mobility, or in the absence of capital mobility but a smaller than one degree of relative risk aversion and a high elasticity of intertemporal substitution (see Proposition 5). Suppose that debt slightly exceeds $\mathrm{D}_{\mathrm{L}}$ and the economy is trapped in the low investrent equilibrium. Then both parties prefer to switch to the high investment equilibrium (see Propositions 7 and 8). The problem is, however, that there do not ist market forces that authomatically bring about a switch. On the other hand, the creditors can orchestrate a switch by a small amount of debt forgiveness, because once debt is below $D_{L}$ the economy moves to the high investment equilibrium. Given I a small amount of debt forgiveness reduces $V(D, I)$ by a small amount. On the other hand, a discrete increase in investment brings about a discrete increase in $V(D, I)$. Therefore in this case debt relief benefits the creditors as well as the debtor (although the creditors prefer a switch to the high investment equilibrium without debt reduction). In this situation debt reduction can perform the important function of a trigger that shifts the economy to a better equilibrium. 
Figure 10 describes the market value of debt as a function of its face velue for the example presented in footnote 2 . In the range $\left[D_{L}, D_{U}\right]$, in which there are two equilibria, the upper curve plots values for the high investment equilibrium while the lower horizontal line plots values for the low investment equilibrium. In this example the low investment equilibrium has always zero investment. For this reason the market value of debt does not change with its face value in the low investment equilibrium. Clearly, in the zero investment equilibrium creditors lose nothing by collectively reducing debt to $D_{L}$, and they stand to gain a lot by a slight further reduction. Hence,

Proposition 11: In the presence of multiple equilibria debt reduction benefits the creditors whenever the economy would otherwise be in the zero investment equilibrium.

The fact that the creditors have a collective incentive to provide debt relief does not imply that individual creditors have the same incentive. This is known as the free rider problem. The following section discusses possible outcomes, taking into account the incentives facing individual creditors.

\section{Equilibrium Debt Reduction}

We have seen that there exist circumstances in which the market value of debt $V[D, I(D)]$ rises with its face value; other circumstances in 
which it rises for low face values and declines for high face values; and that it can in fact drop discontinuousely. Whenever market value rises with face value creditors lose from debt reduction, unless there is more than one investment equilibrium and debt reduction switches the economy from a low to a high investment equilibrium. In the latter case-as well as in the case in which the face value of debt falls into a range in which market value declines with face value--creditors are interested to provide debt relief. This, however, is a collective interest. A frequent argment states that even when debt reduction serves the collective incerest of creditors, a single creditor stands to gain more by not participating in a relief program. Because once debt is forgiven by others, he fully enjoys higher repayments per unit debt without diluting the face value of his holdings. I show that in the single equilibrium case this argument has no justification; a single creditor can benefit from a voluntary reduction of his claims. It may, however, apply in the presence of multiple equilibria.

In order to examine this issue I formulate the relief decision as a noncooperative game among creditors. For simplicity I only discuss symmetric games and their corresponding symmetric equilibria (i.e.,games in which every creditor owns the same face value of debt). First, consider the case in which a single investment equilibrium exists for every level of debt (i.e., $I(D)$ is a function), and the lower panel of Figure 9 describes the market value of debt curve. Equation (6) gives the price of a unit of debt. Taking account of the response of investment to 
changes in debt, the price can also be expressed as

$$
P(D) \equiv P[D, I(D)]
$$

This function declines in $D$.

The game is formulated as follows. A single creditor owns $D / n$ units of debt, where $n$ denotes the number of creditors. He can choose to reduce his holding to $d \leq D / n$. He wishes to maximize the market value of d. Therefore, if the other creditor' holdings after their forgiveness decision is denoted by $\mathrm{D}^{-}$, he solves the following problem:

$$
\max _{d}\left[P\left(D^{-}+d\right) d \mid \text { s.t. } d \leq D / n\right]
$$

This game resembles a Cournot oligopoly in which firms maximize revenue and sales are limited by a capacity ceiling. Assuming that the marginal revenue curve $M R(D)=P(D)+P^{\prime}$ (D) $D$ slopes downward, the symmetric solution satisfies:

A. For $\operatorname{MR}(D) \geq 0 ; d=D / n$ and no debt reduction takes place;

B. For $M R(D)<0$; d is implicitly defined by $m(n d)-0$ and voluntary debt reduction takes place; 
where $m(D)=\frac{1}{n} M R(D)+\left[1-\frac{1}{n}\right] P(D)$ (see Helpman and Krugman (1988, Chap. 4)). ${ }^{13}$ Figure 11 describes this solution. Curve $m(D)$ is located between the demand and the marginal revenue curves; it coincides with the marginal revenue curve when $n=1$ and with the demand curve when there are infinitely many creditors. A single monopoly creditor provides voluntary debt reduction whenever debt exceeds $D_{0}$, where $D_{0}$ in Figure 11 corresponds to $D_{0}$ in Figure $9 .^{14}$ Hence, a single creditor provides relief that maximizes the market value of debt, just like a monopolist who choses output to maximize total revenue in the absence of costs. Seceral noncooperating creditors provide debt reduction to $D_{n}$ whenever $D>D_{n}$. Their joint forgiveness is not as large as the single creditor's, but they do Forgive nevertheless. For every finite number of creditors the noncooperative solution implies debt reduction for sufficiently high debt levels. These results are summerized in the following proposition:

Proposition 12: If there exists free capital mobility or there is no capital mobility but the degree of relative risk aversion is smaller than one, and a single investment level corresponds to every debt level, then:

${ }^{13}$ The individual creditor's marginal revenue is $P\left(D^{-}+d\right)+P^{\prime}\left(D^{-}+d\right) d$. His objective function is maximized when this is equal to zero. When this is achieved at $d \leq D / n$, this is also the solution to (20). If, however, this is achieved at $d>D / n$, his ceiling constraint is binding and he chooses $d=D / n$. In a symmetrical equilibrium we examine marginal revenue $P(n d)+P^{\prime}$ (nd) $d$, which is given by $m(n d)$.

${ }^{14}$ From the definition of $M R(D)$ it is clear that $V[D, I(D)]=P(D) D$ reaches a maximum at $\mathbb{M R}(D)=0$. 
(a) For every finite number of creditors there exists a minimal debt level at which creditors provide voluntary debt reduction.

(b) The minimal debt level increases with the number of creditors, and the post-relief face value of debt exceeds the market value maximizing level (unless $\mathrm{n}=1$ ).

Multiple equilibria introduce new possibilities. In order to clarify. them, consider the example developed in Figures $3,4,5$, and 10 . The demand curve $P(D)$ has two separate portions, as depicted in Figure 12; the upper portion corresponds to equilibria with positive investment while the lower corresponds to equilibria with zero investment. The lower portion is defined by $\mathrm{PD}=\mathrm{V}_{0}$, implying a marginal revenue of zero. Therefore, as long as creditors perceive changes along this curve (namely, they believe that their contribution to debt reduction will not bring about a shift to the positive investment equilibrium), they have no incentive to reduce debt. In these circumstances there exists a noncooperative equilibrium with debt forgiveness only when every creditor is willing to provide the marginal debt reduction that reduces the debt's face value just below $D_{L}$. A direct calculation shows that

$$
\frac{\mathrm{V}_{0}}{\overline{\mathrm{PD}}_{\mathrm{L}}}<\frac{1}{\mathrm{n}}+\left[1-\frac{1}{\mathrm{n}}\right]_{\mathrm{D}}^{\mathrm{D}_{\mathrm{L}}}
$$

is necessary and sufficient for the existance of an equilibrium with debt reduction, where $\bar{P}$ is the price of debt at $D_{L}$ in the high investment 
equilibrium. The left hand side is smaller than one (see Figure 12). ${ }^{15}$ Condition (21) is satisfied when $\mathrm{n}=1$; a single creditor provides relief. For every other $n>1$ there exists $D$ close enough to $D_{L}$ that fulfills (21).

On the other hand, the satisfaction of (21) does not exclude an equilibrium with no debt reduction. The following provides a necessary and sufficient condition for the existence of an equilibrium without debt reiief: ${ }^{16}$

$$
\frac{\mathrm{V}_{0}}{\overline{\mathrm{P}}_{\mathrm{L}}}>\mathrm{n}-(\mathrm{n}-1) \frac{\mathrm{D}}{\mathrm{D}_{\mathrm{L}}} .
$$

Conditions (21) and (22) can be satisfied simultaniousely. For example, they are satisfied when $n=2$ and $D / D_{L}-3 / 2$. Hence,

${ }^{15}$ In a symmetrical equilibrium $D_{L}$ is reached when every creditor forgivess $\left(D-D_{L}\right) / n, D \geq D_{L}$. When $n-1$ creditors forgive their share, the remaining face value of debt is $D_{L}+\left(D-D_{L}\right) / n$ and its price in the secondary market is $V_{0} /\left[D_{L}+\left(D-D_{L}\right) / n\right]$. If the remaining creditor does not forgive, the market value of his claims is $(D / n) V_{0} /\left[D_{L}+\left(D-D_{L}\right) / n\right]$. If he forgives his share, the market value of his claims is $\left(D_{L} / n\right) \bar{P}$. The latter exceeds the former if and only if (21) holds.

${ }^{16}$ when $n-1$ creditors do not provide debt relief, the $n^{\text {th }}$ creditor's debt is worth $v_{0} / n$ if he does not provide relief and it is worth $\bar{P}\left[D / n-\left(D-D_{L}\right)\right]$ if he provides relief $\left(D-D_{L}\right)$ so as to induce a jump to the high investment equilibrium. The former exceeds the latter if and only if (22) is satisfied. 
Proposition 13: If there exist multiple investment equilibria for a given debt level then an equilibrium with debt reduction may coexist with an equilibrium without debt reduction.

This result shows that debt reduction is not guaranteed even when it is an equilibrium phenomenon, because it may coexist with an equilibrium in which there is no debt reduction. Which one emerges depends on expectations. If creditors believe that others will forgive debt, they alsa chose to forgive and debt reduction obtains. If, on the other hand, creditors believe that others will not forgive, they also chose not to forgive and no debt reduction takes place. This happens only when the economy is trapped in a low investment equilibrium. It represents a clear instance in which cooperation has a high return.

\section{Conclusions}

My results show that the desirability and likelihood of voluntary debt reduction depend on circumstances. Creditors benefit from a write-down of debt in some circumstances and lose in others. Theory helps to identify important features of those circumstances. But once those features are known, there is no substitute for a careful examination of their applicability to concrete countries. In particular, estimates of the function $V[D, I(D)]$ are needed in order to form a judgement on whether debt reduction helps the banks. This function can, in principle, be recovered from data on secondary market prices. Unfortunately, these 
FIGURE 2

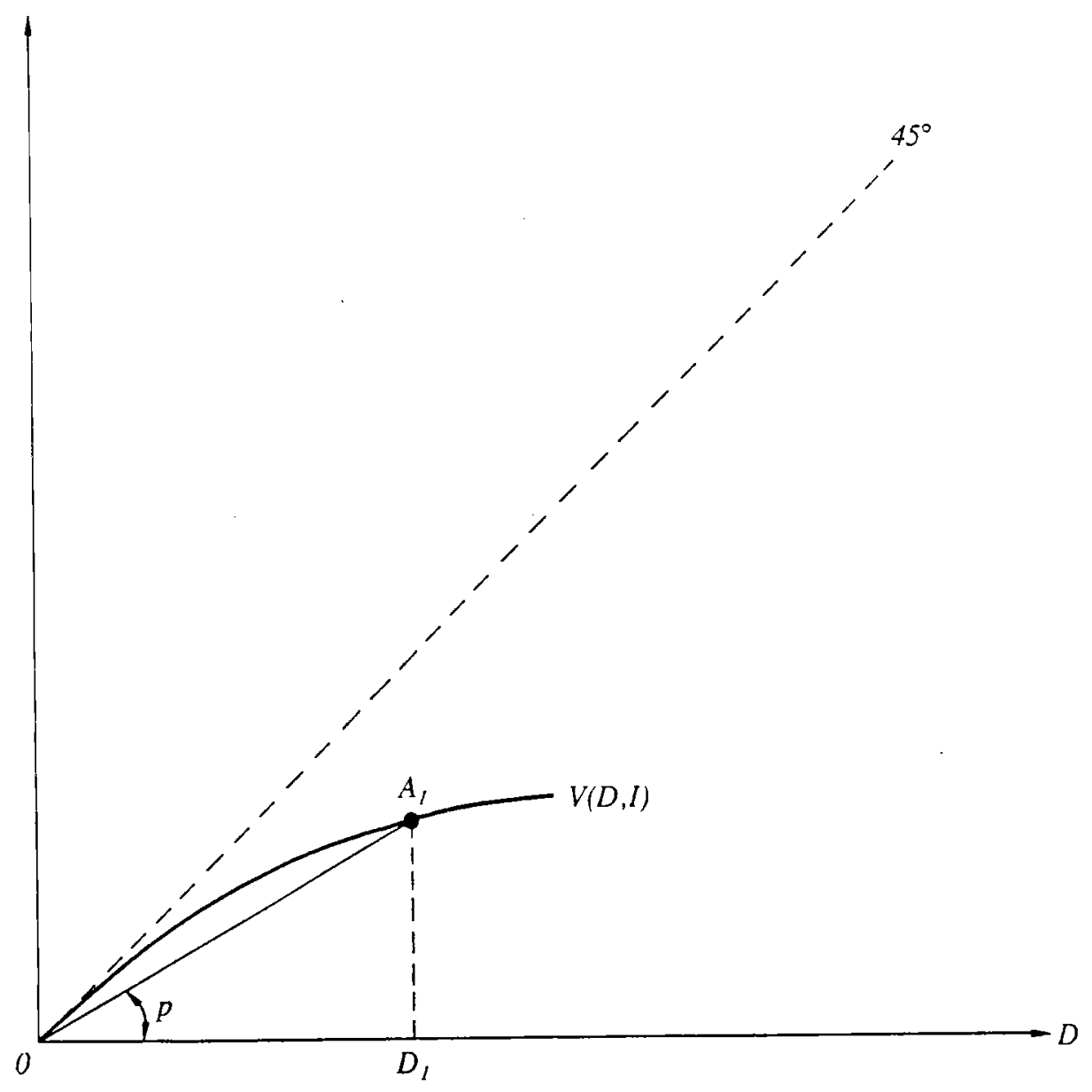


debtor and creditors desire to switch to a high investment equilibrium. Nevertheless, warket forces may not bring about a switch. In this case voluntary debt reduction can play a useful role in inducing the desired switch. However, debt redcution fails to fulfill this role if expectations are pessimistic. In this case the debtor country government can improvement on the free market outcome.

Suppose, for example, that lump-sum taxes are available in the debtor country in the first period. Then the government can use them in order to raise revenue and subsidize investment. An investment subsidy shifts down the $q_{s}(\cdot)$ curve (see Figure 4 ) and thereby raises invesment at every stable equilibrium. In addition, sufficiently high subsidies eliminate the zero investment equilibrium, thereby benefitting the debtor and the banks. But lump-sum taxes are seldom available. Therefore an optimal policy from the debtor's point of view needs to take into account the dead-weight loss associated with the use of distortionary taxes. This dead-weight loss tilts the cost-benefit analysis against investment subsidies.

I have described several examples of policy applications. There are many other policies that can be considered, such as alternative forms of taxation, changes in public spending, and control of international capital flows. The desirability of debt reduction depends on these policies. 


\section{References}

Calvo, Guillermo A., "Servicing the Public Debt: The Role of Expectations," American Economic Review , 1988 (forthcoming).

Claessens, Stijn, "The Debt-Laffer curve: Some Estimates," mimeo, July 1988.

Cline, William R., Mobilizing Band Lending to Debtor Countries, Policy Analysis in International Economics 18, Institute for International Economics, Washington, DC, June 1987.

Corden, Max W., "An International Debt Facility?," International Monetary Fund Working Paper $88 / 16,1988 \mathrm{a}$.

"Debt Relief and Adjustment Incentives: A Theoretical Exploration," International Monetary Fund Working Paper 88/36, $1988 \mathrm{~b}$.

"Is Debt Relief in the Interest of the Creditors?," mimeo, $1988 \mathrm{c}$.

Diamond, Peter A., "The Role of a Stock Market in a General Equilibrium Model with Technological Uncertainty," American Economic Review, 57, $1967,759-776$. 
Dooley, Michael P., "Buy-backs and Market Valuation of External Debt," Internationa1 Monetary Fund Staff Papers, 35, 1988, 215-229.

Eaton, Jonathen, "Public Debt Guarantees and Private Capital Flight," The World Bank Economic Review, 1, 1987, 377-396.

Froot, Kenneth A., "Buybacks, Exit Bonds, and the Optimality of Debt and Liquidity Relief," mimeo, 1988.

Helpman, Elhanan, "The Simple Analytics of Debt-Equity Swaps and Debt Forgiveness," International Monetary Fund Working Paper 88/30, 1988.

and Krugman, Paul R., Market Structure and Trade Policy, mimeo, 1988 .

- and Razin, Assaf, A Theory of International Trade under Uncertainty, New York: Academic Press, 1978.

Kenen, Peter B., New York Times, 6 March 1983.

Krugman, Paul R., "Market-Based Debt-Reduction Schemes, " NBER Working Paper No. 2587, 1988. 
Sachs, Jeffrey, "The Debt Overhang of Developing Countries," in Ronald Findlay (ed.), Debt, Growth and Stabilization: Essays in Memory of Carlos Diaz Alejandro, Oxford: Blackwell, 1988. 
FIGURE 1

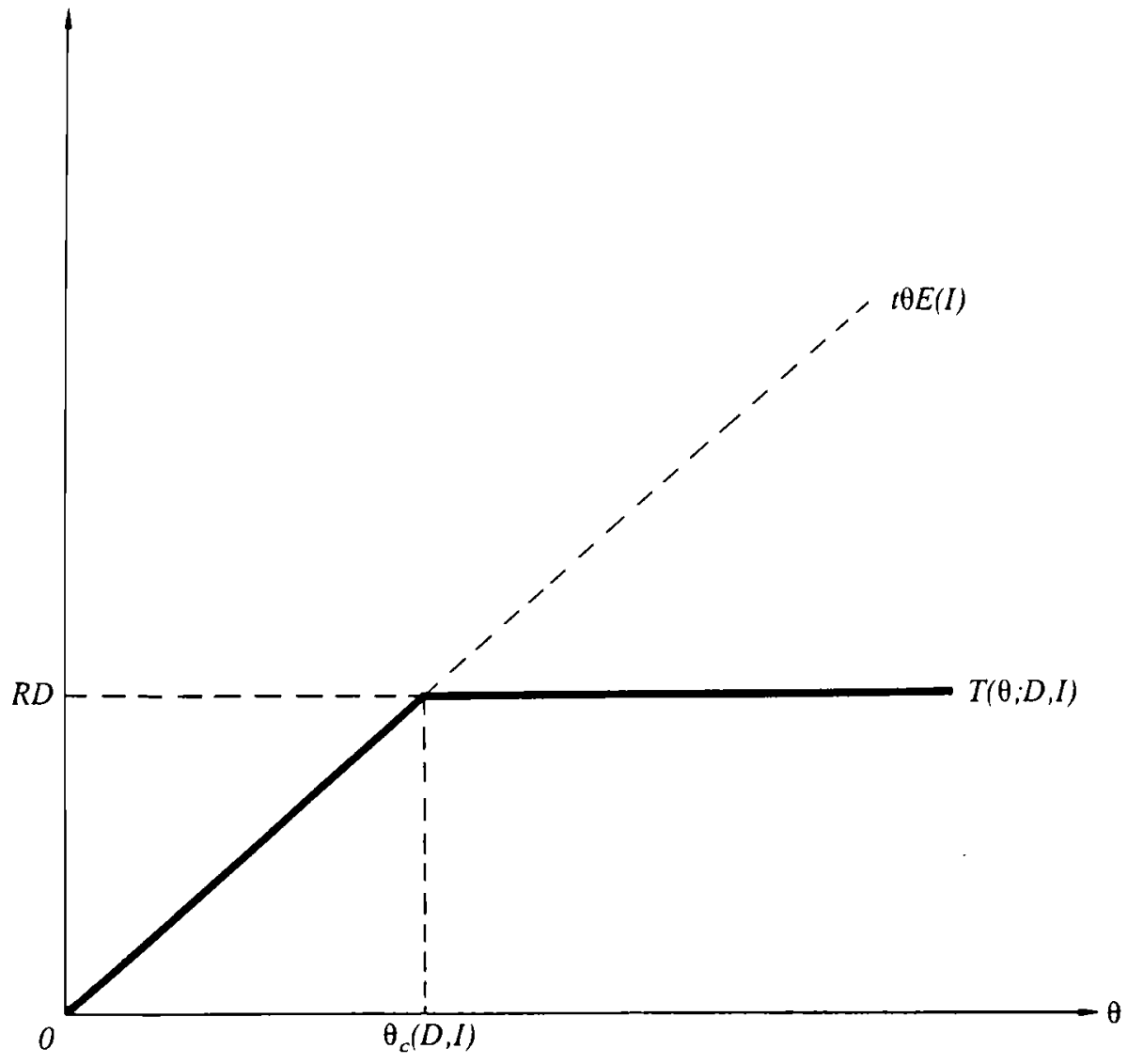


FIGURE 2

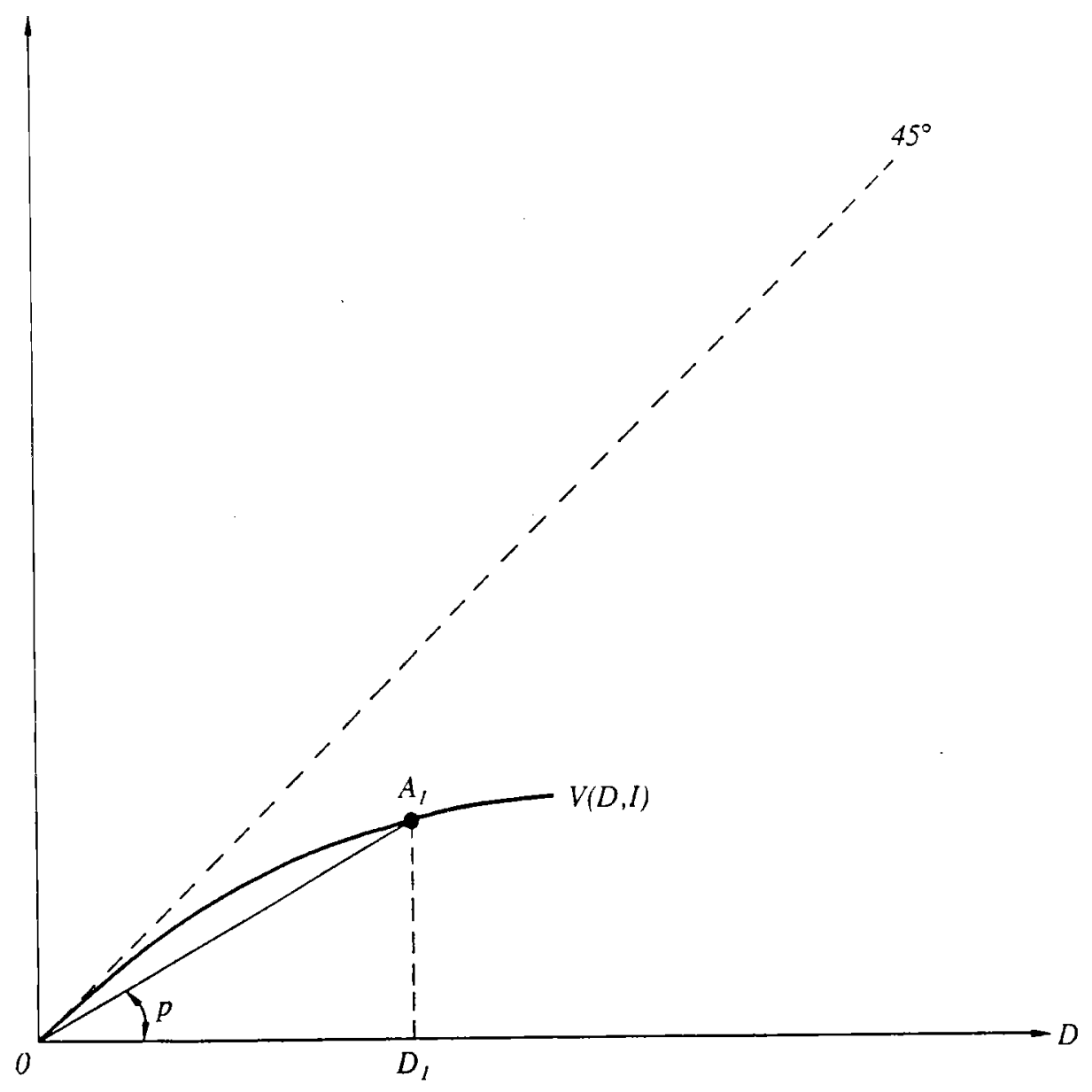


FIGURE 3

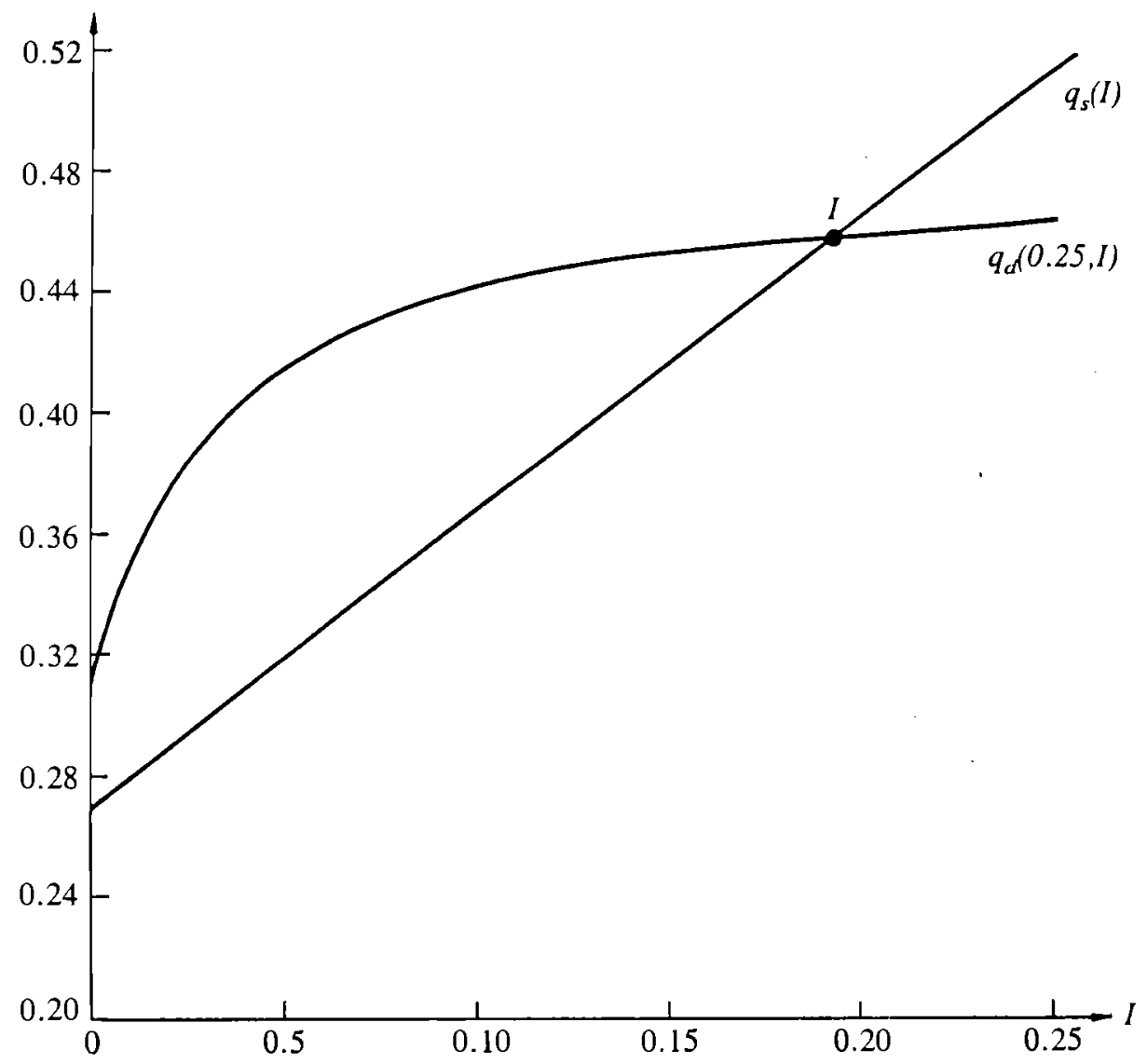


FIGURE 4

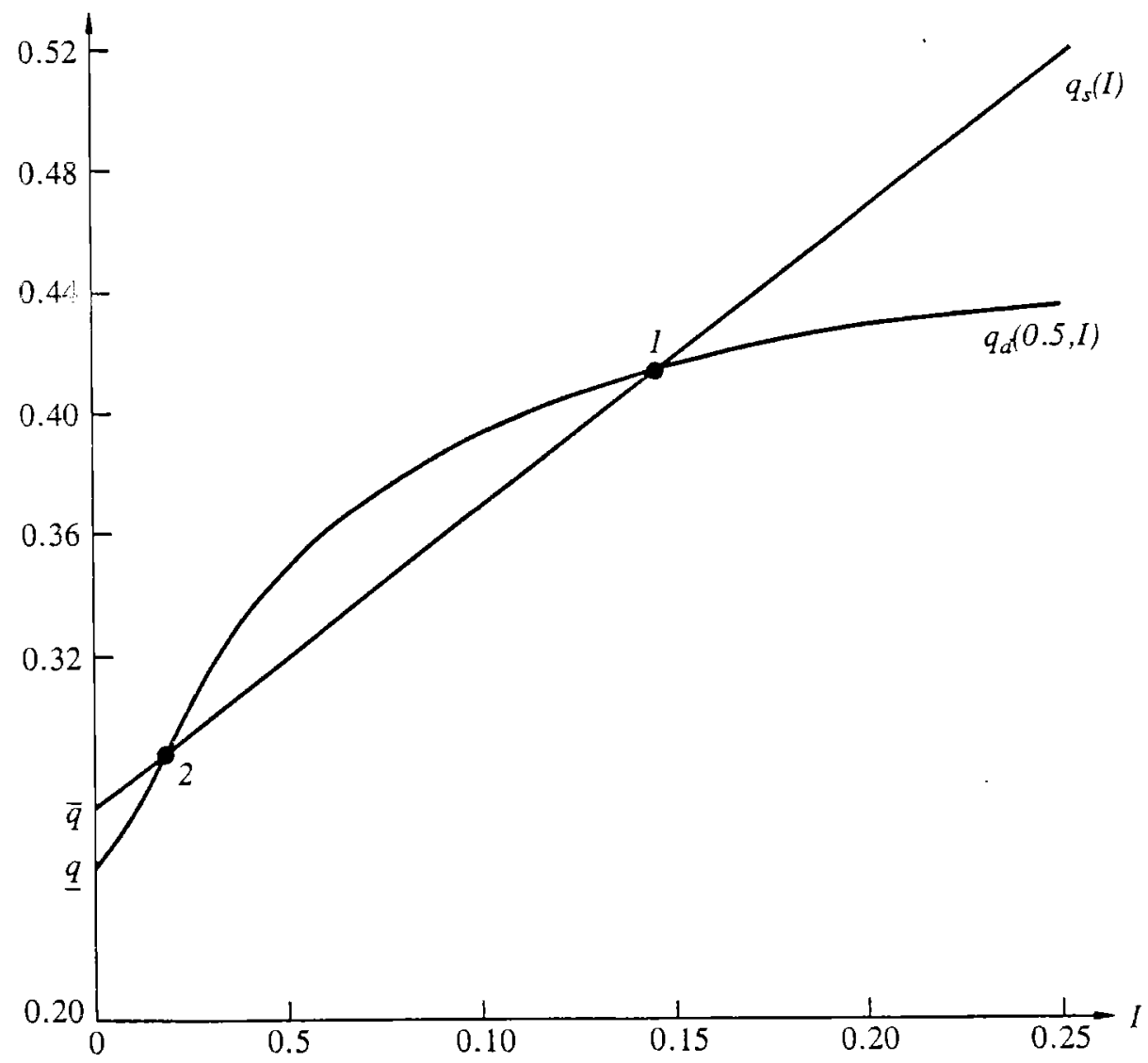


FIGURE 5

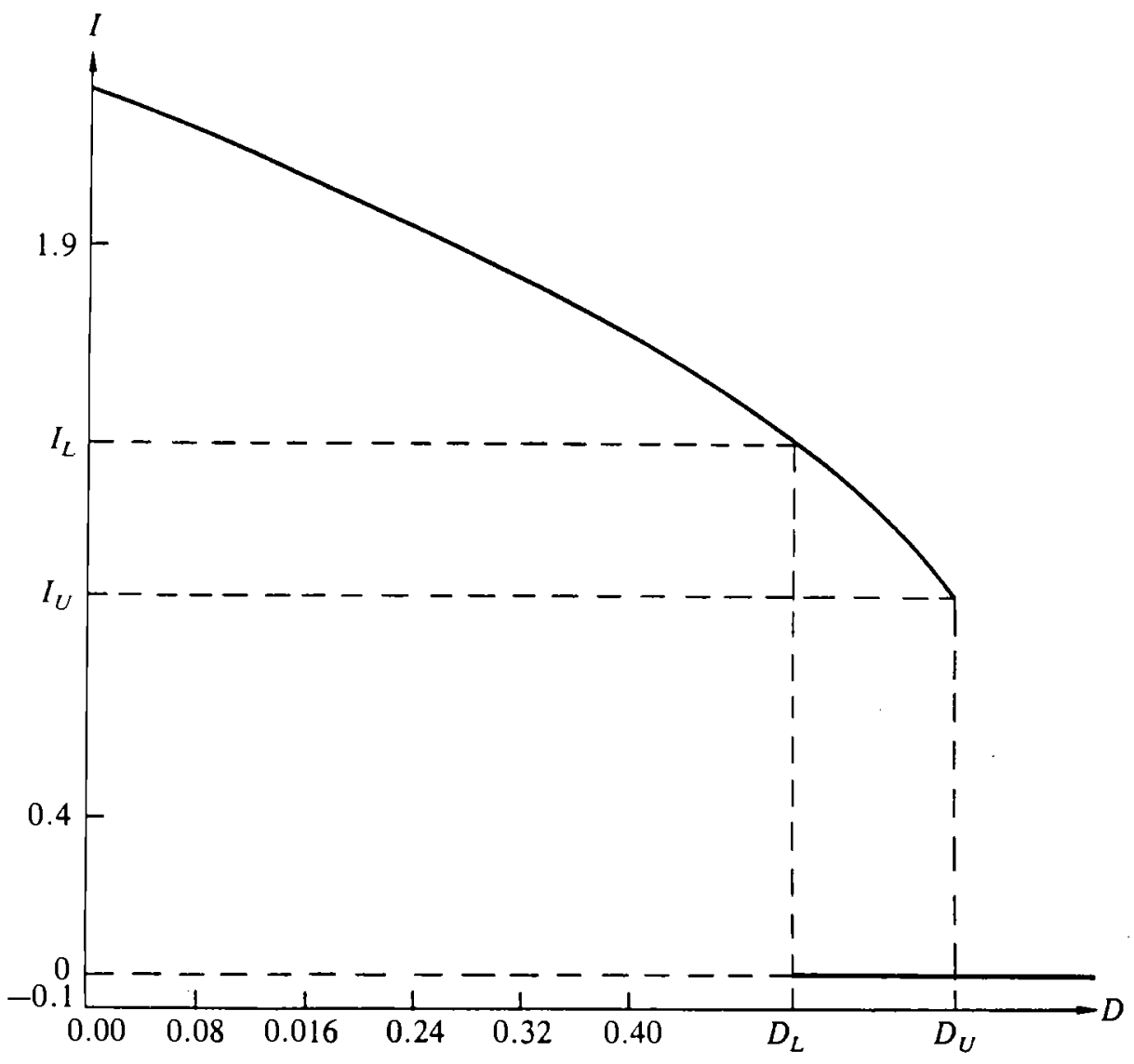


FIGURE 6

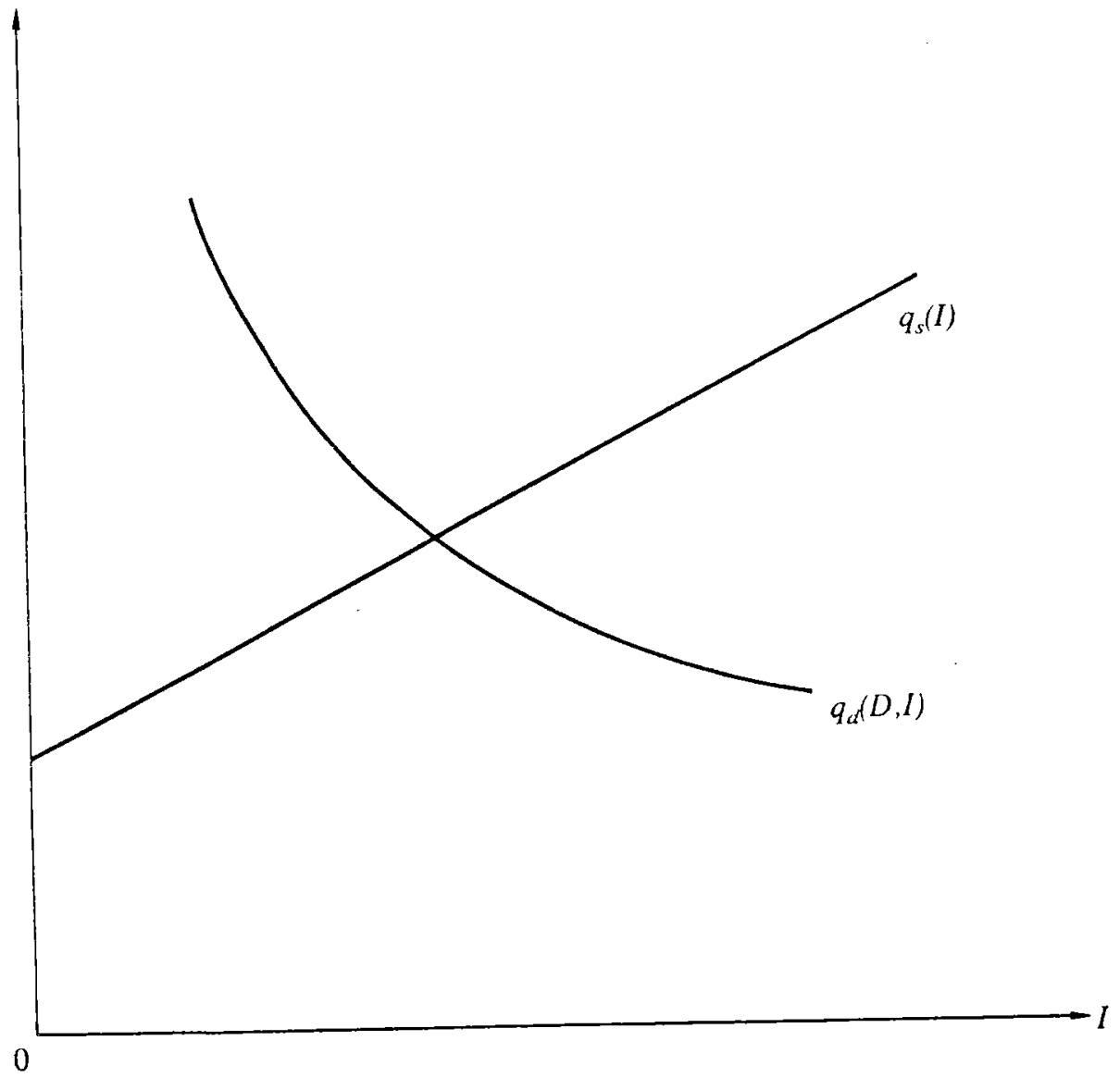


FIGURE 7

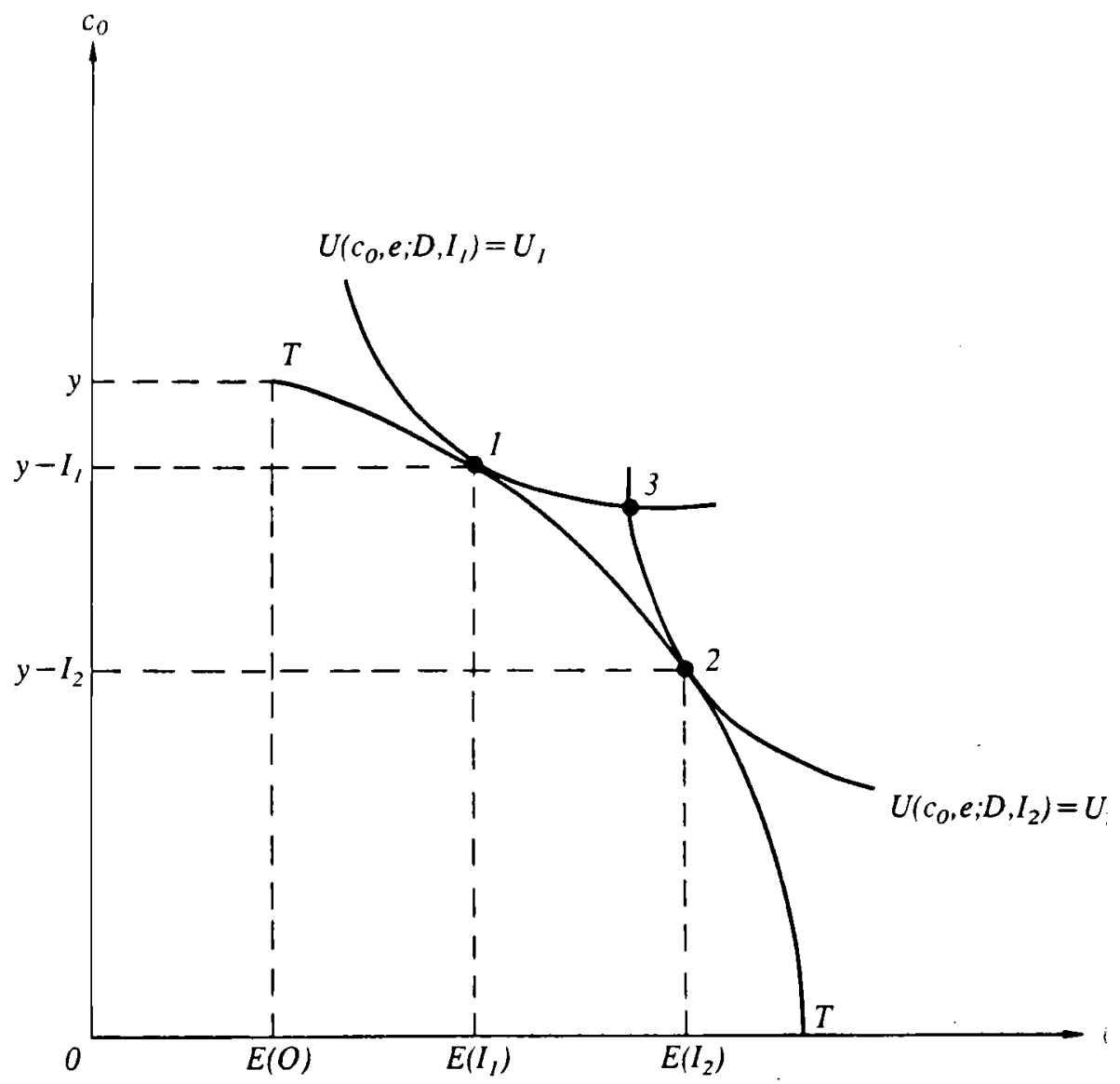


FIGURE 8

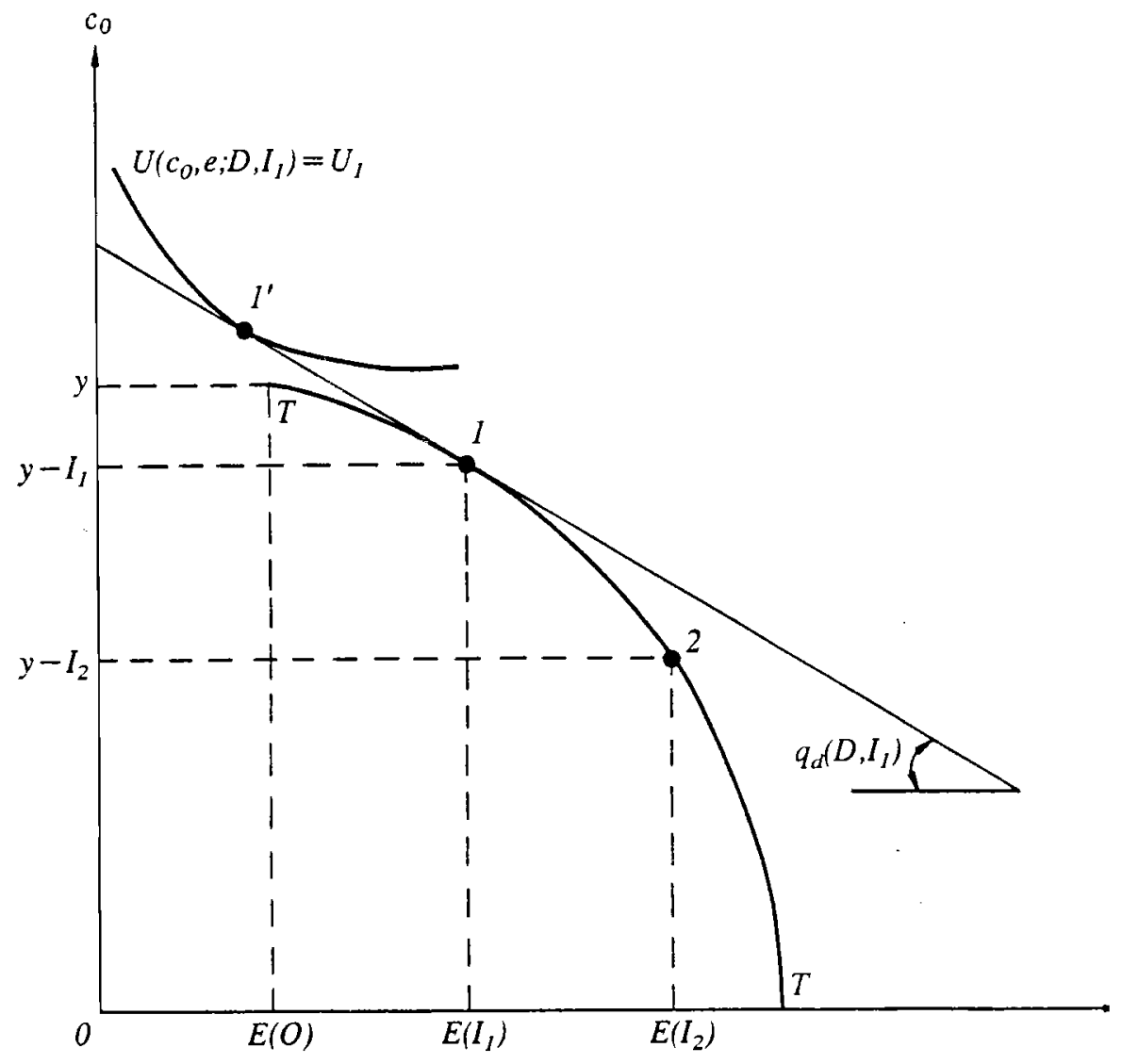



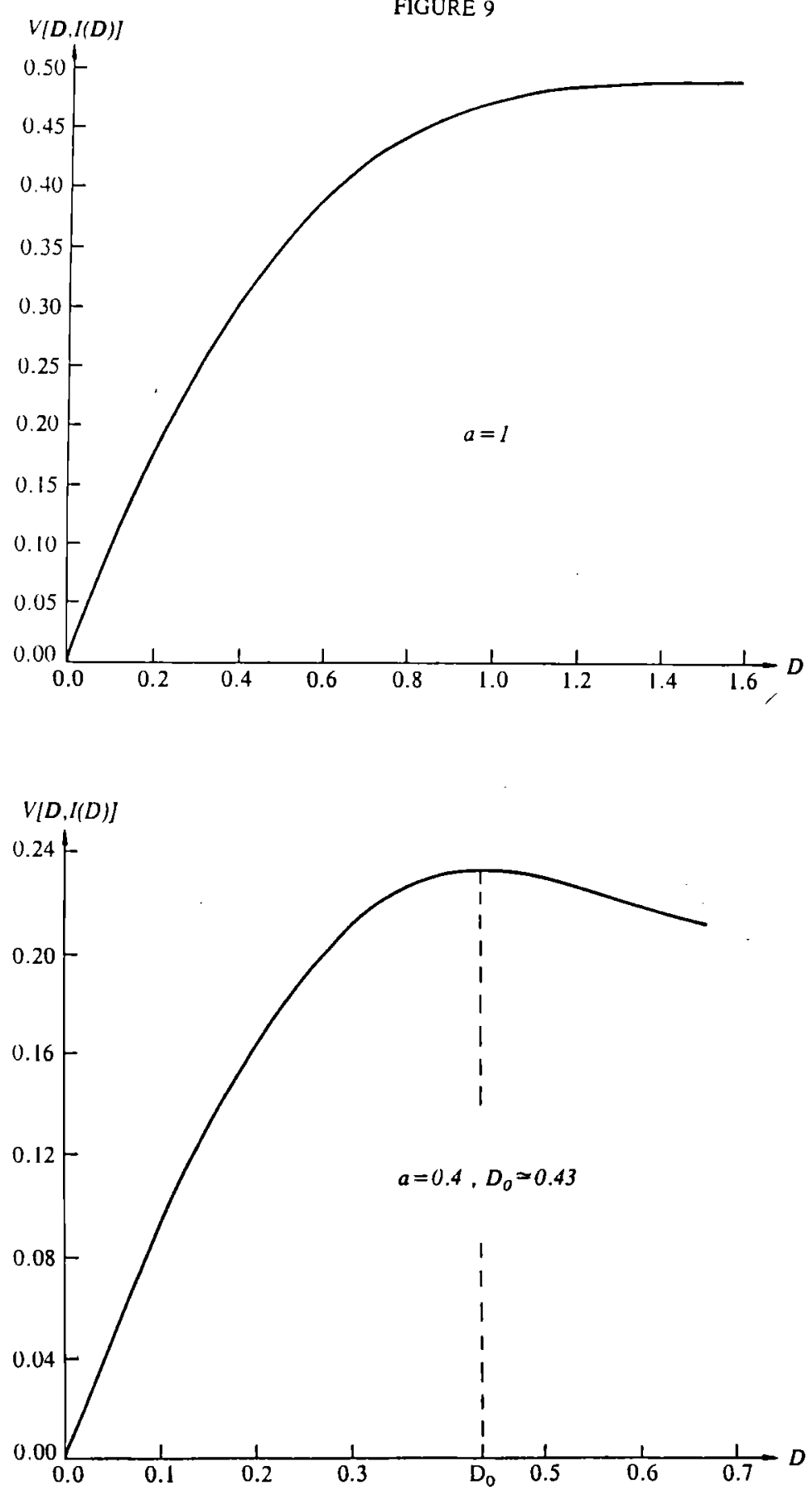


\section{FIGURE 10}

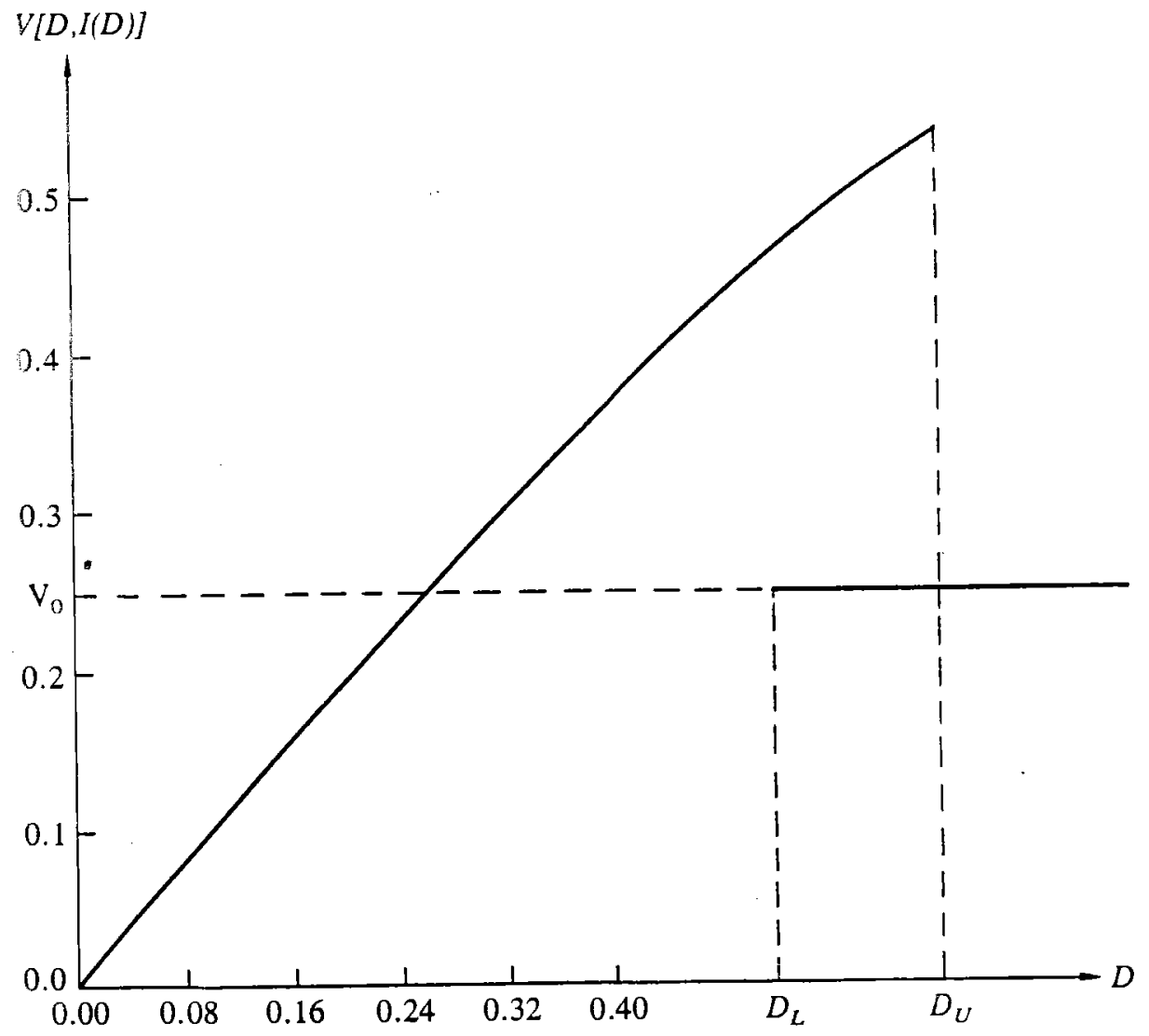


FIGURE 11

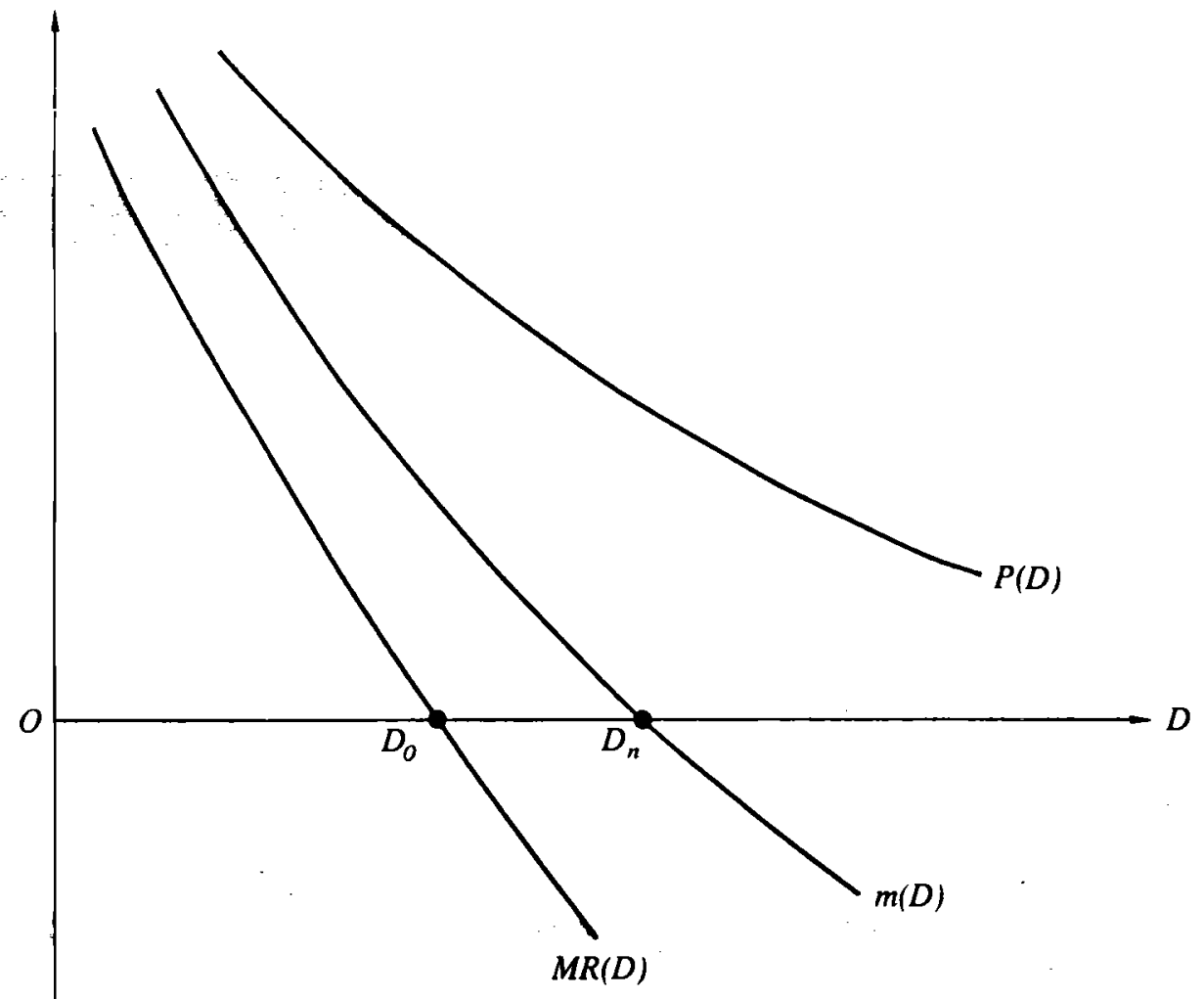


FIGURE 12

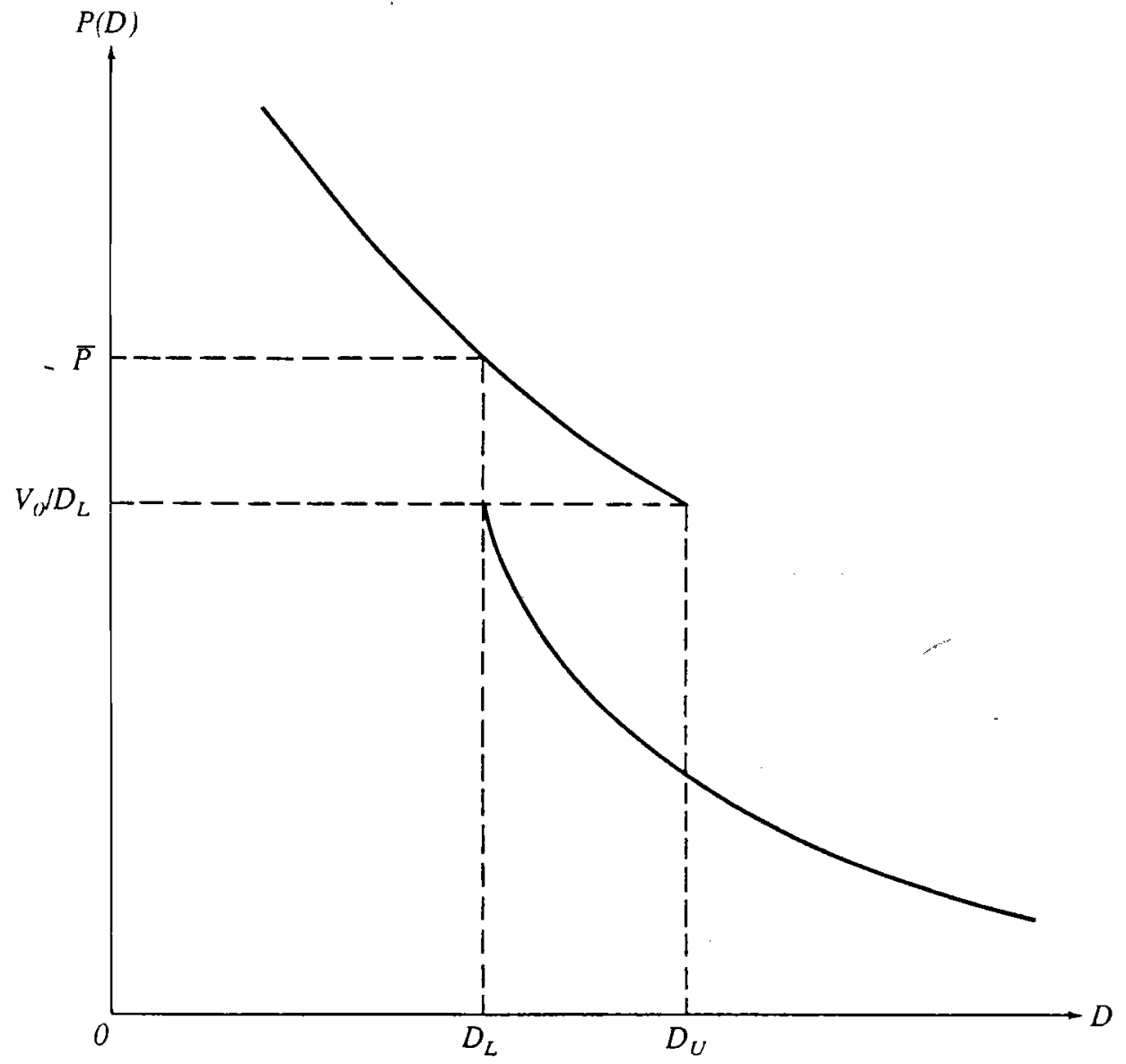

